\title{
Könyvszemle
}

SIPOS JÚLIA GONDOZÁSÁBAN

\section{A 90 ÉVES CHOMSKY JELENTŐSÉGE ÉS HATÁSA A NYELVTUDOMÁNYBAN, A PSZICHOLÓGIÁBAN, A MEGISMERÉSTUDOMÁNYBAN, A FILOZÓFIÁBAN ÉS AZON TÚL: SZABADSÁG, BÁTORSÁG ÉS TARTÁS}

Noam Chomsky 2018. december 7-én ünnepelte 90. születésnapját. Így szoktuk ezt mondani, de szinte biztos vagyok benne, hogy ö maga ezt nem ünnepelte. Talán attól is kissé kényelmetlenül érezi magát, ahogy mások őt ünnepelték, és ünneplik ma is, mint a szerkesztő és a szerzők a Nyelv, biológia, szabadság: A 90 éves Chomsky jelentösége a tudományban és azon túl címü kötetben. A 90 éves nagy hatású gondolkodót s közvetve a tudást és a tudományt ünnepli a szerkesztőt is beleértve három nyelvész, két pszicholingvista és megismeréstudományi kutató, egy filozófus, egy matematikus, egy kommunikáció- és médiatudományi és egy politikatudományi kutató a Kenesei István szerkesztette kilenc tanulmányt tartalmazó kötetben (beleszámítva a szerkesztő általa szerényen előszónak titulált dolgozatát).

E recenzió ügyetlen és hosszú (bár még így is hiányos) felsorolásszerü címében egyrészt azok a tudásterületek szerepelnek, amelyekben Chomsky munkássága vagy azonnal és közvetlenül - mint a nyelvtudományban, a pszichológiában és a megismeréstudományban -, vagy közvetve és kisebb-nagyobb késéssel radikális átalakulást hozott, másrészt olyan emberi értékek, amelyeket Chomsky maga képvisel, illetve megtestesít. Chomskytól nemcsak a nyelvről és a nyelvtudományról tanulhattunk és tanulhatunk hatvan év elteltével is sokat, hanem arról is, hogy miben áll az a bátorság és tartás, amellyel egy tudós kiáll olyan radikálisan új nézetei mellett, amelyeket egyrészt megérteni sem könnyü - első kéziratait nem is igen értette senki rajta és néhány barátján kívül -, másrészt annyira különböznek a domináns kortárs felfogástól, hogy világos: vagy Chomsky téved, vagy - ha neki igaza van, akkor - mindenki más. Chomsky tartása és a tudományos megismerés iránti példamutató alázata abban is rendszeresen megnyilvánult, hogy volt bátorsága - nemegyszer elsőként - nyilvánosan rámutatni néhány korábbi saját tévedésére, pontosabban: felfogásának egy-két olyan elemére, amelyet legalábbis ő maga tévedésnek tartott. Tegyük hozzá gyorsan, hogy ez sosem merült ki a merő meakulpázásban. Épp ellenkezőleg: minden egyes alkalommal - legutóbb a 90-es 
évek elején, amikor elóállt a nyelvészet minimalista programjára vonatkozó javaslatával - a nyelvtudományt kívülről (értsd: metaelméleti aspektusból) is és belülről is megújító és sokakat inspiráló hipotéziseket tett le a tudomány asztalára.

A szerkesztő általa előszónak nevezett dolgozatát követő négy tanulmány - minden bizonnyal a szerkesztő tudatos szándéka szerint - sorrendben nagyjából megfelel annak, ahogy Chomsky nézetrendszere történetileg változott, és annak, ahogyan e nézetek hatására mások nézetei változtak, olykor radikálisan - nemcsak a nyelvtudományban, hanem azon kívül is. Kulcsszavakban összefoglalva: a nyelv mint generatív szabályrendszer (Dékány Éva: Chomsky nyelvészeti radikalizmusa); a nyelv mint mentális generatív szabályrendszer, azaz kompetencia (Pléh Csaba: Chomsky és a pszichológia); a nyelv mint mentális generatív szabályrendszer tanítás nélküli elsajátitása gyermekkorban (Gervain Judit: Chomsky hatása a nyelvelsajátitás kutatására); bionyelvészet: az embergyerek veleszületett fajspecifikus nyelvi képessége, amely lehetővé teszi egy bizonyos, a környezet nyelvi ingereire hangolt mentális generatív szabályrendszer létrehozását (Bódy Mihály: Néhány bionyelvészeti megjegyzés).

Ha akarom, legalább a saját mondanivalóm kedvéért, még az ezek után következő dolgozatot, Forrai Gábor Chomsky és a filozófiai szemantika című tanulmányát is bele tudom illeszteni az iménti gondolatmenetbe. A dolgozat sorrendi helye legalábbis megfelel annak a történeti ténynek, hogy Chomskynak a tudással és a megismeréssel kapcsolatos álláspontja épp a filozófiában maradt jószerivel hatástalan. Az egyetlen nyilvánvaló és jelentős kivétel Wolfram Hinzen. Öt és a Chomsky hatására - bár részben Chomsky ellenében - kidolgozott unkarteziánus nyelv- és ismeretelméletét több okból is fontos legalább megemlíteni. Az egyik ok már az előző mondatban is szerepel: Hinzen Chomsky hatására dolgozta ki az emberi gondolkodás és megismerés ,generatív” elméletét, amely szerint nem véletlen a figyelemre méltó szerkezeti hasonlóság és kényelmes illeszkedés az ember kijelentésszerü propozicionális gondolatai és mondatai között: mind a kijelentéseket, mind a mondatokat egyazon komputációs rendszer, a nyelvi szintaxis hozza létre. Hinzen elmélete kiküszöböli azt a jól ismert problémát, hogy egyébként két szintaxissal kell számolni: egy nyelvivel, amelyik a mondatokat hozza létre, és egy másikkal az „elme nyelvében”, amely a propozicionális gondolatok megalkotója. Hinzen elmélete egy másik problémát is megold azzal, hogy a probléma eltűnik: Nincs többé szükség afféle korrespondencia-szabályokra, amelyek az említett két kognitív modul termékeinek egymáshoz rendeléséről adnak számot a gondolkodás-nyelv interfészen, mert - legalábbis a kijelentésszerü gondolatok tekintetében - nincs efféle interfész; a gondolatok is és a mondatok is ugyanott, egyszerre, és egymástól elválaszthatatlanul születnek.

Meglepő módon, ez érintkezik Bródy Mihály Néhány bionyelvészeti megjegyzés címú tanulmányában felvetett hipotézisével, amely első látásra szöges ellentétben áll Hinzen felfogásával. De van legalább két lényeges közös vonásuk. Egyrészt 
mindkettejük szintaxiselmélete eltér a chomskyánus generatív nyelvtanban bevett szintaxisfelfogástól és ezzel összefüggésben a mentális nyelvtan s a vele érintkező interfészmodulok közötti munkamegosztással kapcsolatos feltevésektöl: Hinzen tágítja a szintaxis szerepét, Bródy szükíti. Másrészt abban is hasonló e két nyelvelmélet, hogy mindkettőben egyazon rendszer hozza létre a mondatokat és a mondatokban kifejeződő fogalmi konstrukciókat. Az utóbbi tekintetében az a különbség kettejük felfogása között, hogy Hinzen elméletében ez a szintaxis dolga, míg Bródyéban a fogalmi konstrukciókat létrehozó interfészrendszeré, Chomsky terminusával a konceptuális-intencionális rendszeré. Bródy a mondatalkotás feladatát az ily módon némileg elszegényített szintaxisból a fogalmi gondolkodás rendszerébe utalja, gazdagítva ezzel a gondolkodás szintaxisát. Hinzen épp fordítva: a propozicionális gondolkodás szintaxisát teljes egészében kiemeli a fogalmi-konstrukciós rendszerből, és mind a fogalmi, mind a nyelvi konstrukciót a hagyományosan szüken értett mondatkonstrukcióra dedikált szintaxis feladatává teszi.

Nem Hinzen az első filozófus, aki az emberi nyelv kérdéseihez is hozzászól. Bár talán ő az első, aki elegendően explicit és igényes módon teszi ezt ahhoz, hogy a nyelvészek számára is értelmezhető és érdekes legyen, amit mond. Amikor például egy filozófus mondatokról és azok jelentéséről beszél, résen kell lenni, mert - Hinzentől eltérően - a mondat terminuson többnyire nem azt értik, amit a nyelvészek. Ez fordítva is érvényes, filozófusokra és mindenki másra is a nyelvtudományon kívül. Nekik is érdemes számolniuk azzal, hogy az ő mondafogalmuk nem föltétlenül azonos azzal, amit a nyelvészek használnak.

Nem vonom kétségbe, hogy Forrai Gábornak igaza van, amikor azt állítja, hogy „Az angolszász filozófusok között gyakorlatilag teljes egyetértés van abban, hogy... a mondatok jelentését azzal jellemezzük, hogy milyen körülmények között igazak, azaz hogy mik az igazságfeltételeik" (128.). Ám ebböl nem következik - és ezt Forrai sem sugallja -, hogy maguknak az angolszász filozófusoknak is igazuk van. Ha mondaton nyelvi szimbólumok (szintaktikailag) strukturált halmazát értjük - ahogy a nyelvészetben szokás -, akkor bizony minden olyan filozófus téved, aki az így felfogott mondatokhoz igazságértékeket rendel, és igazságfeltételeikben próbálja megragadni a jelentésüket. Azért tévednek, mert strukturált nyelvi szimbólumoknak nincs igazságértékük, ennélfogva igazságfeltételekkel sem hozhatók közvetlenül kapcsolatba.

A filozófusok között legalább ilyen teljes az egyetértés abban, hogy az ,igaz” vagy „hamis” igazságértékek kijelentésekhez rendelhetők, és hogy ugyanez érvényes az igazságfeltételekre is: azok kijelentések igazságfeltételei. Tehát, az igazságfeltételek nem közvetlenül mondatokhoz, hanem a (bizonyosfajta) mondatokban kifejeződő kijelentésekhez tartoznak. Az ilyen, kijelentéseket kifejező mondatok jelentésének valóban lényeges aspektusa, hogy a bennük kifejezett kijelentések milyen feltételek teljesülése mellett igazak. Ám egyrészt nem minden mondat fejez ki kijelentést: a deklaratív mondatok igen, de például már a kérdő 
mondatok sem. Másrészt a deklaratív mondatok jelentése sem merül ki abban a kijelentésben, amelyet kifejeznek. Az A kutya megharapta a postást mondat jelentéséhez nemcsak egy kijelentés tartozik, hanem egy esemény is, amelyet a mondat ábrázol. Ezért az ilyen mondatok jelentése sem jellemezhető kimerítően úgy, hogy megadjuk azokat a feltételeket, amelyeknek teljesülniük kell ahhoz, hogy a mondatban kifejezett kijelentés igaz legyen. Ezért a filozófiai szemantikában számolni kell azzal, hogy az csak bizonyosfajta mondatoknak egyfajta jelentéséröl, a deklaratív mondatok propozicionális jelentéséröl ad számot, de ebben nem merül ki még a deklaratív mondatok jelentése sem.

A kötet további három dolgozatára az eddigi, talán nem teljesen alaptalan gondolatmenet már nem érvényes. Kornai András Az ellenforradalmár címü Chomsky-kritikájára egyrészt azért nem, mert ebben a szerző Chomsky korai munkáiról ad áttekintést. Másrészt azért nem, mert a szerző a többiekétől eltérő és szokatlan módját választotta a köszöntésnek: bírálja a fiatal Chomskyt - és implicite az időst is -, amiért nem volt elég fogékony a statisztikus gondolkodásra, s ragaszkodott a nyelv determinisztikus magyarázó elméletéhez.

A kötetet Tóth Benedek Társadalomkritika és az egyetértés gépezete és Antal Attila Noam Chomsky politikai gondolkodása címủ dolgozata zárja. Ezek sorrendiségébe már csak azért sem szabad semmiféle történetiséget beleolvasni, mert Chomsky életmủvében nemcsak párhuzamos a nyelvtudományi munkásság és a politikai aktivizmus, hanem valójában korábban - már kamaszkorában - nemcsak érdeklődött a tágan értelmezett társadalmi és politikai kérdések iránt, hanem írt is róluk. Nem tudjuk, hogy mi történt volna Chomskyval (és a nyelvtudománynyal), ha nem találkozik a strukturalista nyelvész Zellig Harrisszel a Pennsylvániai Egyetemen, de az a szerkesztői előszóból is tudható, hogy Chomsky és a nyelvtudomány, illetve Chomsky és Harris találkozásában döntő szerepet játszott a fiatal Chomsky társadalmi kérdések iránti korai érdeklődése és kettejük - és a két család - társadalmi-politikai nézeteinek rokonsága.

A kötet dolgozatait nem egyformán könnyű olvasni és érteni, attól függően, hogy az olvasó mennyire járatos a nyelvészet, a pszichológia, a matematika és a filozófia kérdéseiben. Dékány Éva Chomsky nyelvészeti radikalizmusa címü tanulmányában az olvasó iránti elismerésre méltó megbecsüléssel törekszik arra, hogy minél egyszerübben és érthetőbben magyarázza el a generatív nyelvtan radikális újításokat hozó fogalmait, és tisztázzon néhány ezekkel kapcsolatos népszerü félreértést. Elismerésre méltó az is, amilyen sikerrel teszi ezt. De épp a félreértések elkerülése végett szükséges megjegyezni, hogy az, amit a mondatok felszíni szerkezetéről mond - talán az egyszerü és közérthető fogalmazásra való törekevés miatt - olyan közérthetöre sikerült, hogy az már félrevezető. Nem igaz, ti. hogy a mondatok felszíni szerkezete „közvetlenül... érzékelhető - azaz nyomtatásban látható, szóban hallható" (27-28.). Tegyük most félre az írás és nyomtatás kérdéseit, és tekintsük azt, hogy mi hallható szóban, és mi nem. Mondatok 
semmilyen formában nem. A mondatok „felszíni” szerkezetéből nem hallható szinte semmi azokban a hagyományosan megnyilatkozásoknak nevezett akusztikai szignálokban, amelyek egy beszélő száját elhagyhatják. A mondatok felszíni szerkezete valójában igen absztrakt struktúra, amely bizonyos tekintetben még az ún. mélyszerkezetnél is gazdagabb és összetettebb. Például minden olyan nyelvben, amelyben a kérdőszó végső felszíni szerkezetbeli helye a mondat élén van, a kérdő mondat felszíni szerkezete tartalmaz egy nyomot vagy - most a szokásosnál kicsit lazábban értve - ki nem ejtett másolatot a kérdőszó eredeti, kimozdítás előtti helyén. (Pontosabban, nem a kérdőszó eredeti helyén, hanem a mozgatás során elfoglalt helyein vannak a másolatok, de ez most nem különösebben lényeges.) Minden ilyen nyom vagy másolat eleme egy mondat felszíni szerkezetének, amely viszont sohasem hallható, és sohasem figyelhető meg közvetlenül. Ami szóban hallható, esetleg írásban olvasható és közvetlenül megfigyelhetö, az sosem egy mondat. A mondatok a fejünkben jönnek létre, és ott is maradnak; onnan sosem távoznak a szánkon keresztül, és papírra sem lehet őket vetni.

Chomsky munkássága közvetlenül eléggé nyilvánvalóan a nyelvészetre és a pszichológiára volt a legnagyobb hatással. Felforgatta mindkettőt. Az előbbit közvetlenül azzal, hogy újradefiniálta: tárgyául a beszélők nyelvtudását és e tudás elsajátítását közvetlenül lehetővé tevő, velünk született nyelvi képességet tette meg. Ezzel egyszersmind legitimmé vált az emberi elme vizsgálata, amit George Miller „,közbenjárására” (lásd Pléh Csaba tanulmányát ugyanebben a kötetben) - aki eladdig maga is behaviorista pszichológiát tanított a Harvardon - szinte azonnal magáévá tett néhány kortárs pszichológus, a nyelvészethez hasonló módon újradefiniálva a pszichológiát. Ez volt az ún. kognitív fordulat a nyelvtudományban és a pszichológiában. Chomsky munkásságának ezekkel a radikális tudományos fordulatokat hozó hatásaival foglalkozik Pléh Csaba (Chomsky és a pszichológia) és Gervain Judit (Chomsky hatása a nyelvelsajátitás kutatására) tanulmánya.

Gervain Judit, miután mintaszerüen elmagyarázza egyrészt azt, hogy miben állt maga a kognitív forradalom, másrészt azt, hogy mi volt ennek a jelentősége az ember és az ő nyelvi képességének a megértésében, részletesen megtárgyalja a nyelvelsajátítás néhány generatív nyelvészeti modelljét, kitérve számos érdekes és jelentős kísérletre is. Elmagyarázza például - azt is, hogy maga Chomsky hogy magyarázta el -, hogy a nyelvelsajátítás problémája föl sem vetődhetett a kognitív fordulat elött, és hogy miért volt súlyos és alapvető félreértés az inger-válaszmegerősítés fogalmain alapuló behaviorista álláspont.

Pléh Csaba sok, többféle és több szinten értelmezhető mondanivalója alig foglalható össze pár mondatban. Nem tudom, hogy csinálja, de mostani tanulmányában is tud szólni a beavatottakhoz is és azokhoz az olvasókhoz is, akik nála kevésbé járatosak a kognitív pszichológia, a nyelvészet, a megismeréstudomány, a filozófia és tudományelmélet kérdéseiben. Kulcsszavakban: a kognitív fordulat a nyelv és ember mivoltunk megértésében, mentalizmus az emberi lényeg/termé- 
szet megértésében, nyelvészeti mentalizmus, nativizmus, kreativitás a nyelvben és a nyelvi viselkedésben, a nyelv pszichológiai realitása, a pszicholingvisztikai Chomsky-hatás szakaszai, az emberi elme komputációs modellje, az ember veleszületett nyelvi képességének evolúciója, az emberi nyelv és szabadság egymásba fonódó kérdései. A szerző - sok egyéb mellett - elmagyarázza, hogy mi a jelentősége annak, amit Chomsky a kreativitásról mond: hogy „a kreativitás nem pusztán kiemelkedő müvészek vagy tudósok sajátja... [sem] nem valamiféle statisztikai ritkaság”, hanem „maga a [kognitív] rendszer kreatív”, ezért „minden ember kreatív" nemcsak nyelvi, hanem szélesebb kognitív értelemben is (60.).

A szerző azt is segít megérteni, egyrészt hogy mit jelent az, hogy a nyelvészet ma már nem más, mint a kognitív pszichológia egyik ága, másrészt hogy miért nem esik ettől kétségbe egyetlen generatív nyelvész sem, mert „oda az autonóm tudományuk". Néhány más tudomány - vagy a tudomány rangjára és elismertségére vágyó tömeges foglalatosság - tanulhatna ebböl.

A kötet minden egyes dolgozatára érvényes, hogy legalább kétszer olyan izgalmas, érdekes és tanulságos, mint amennyire ebből a kiegyensúlyozatlan és elfogult ismertetésből kitűnik. Hozzáértés híján méltatlanul kevés szó esett a kötetet záró két dolgozatról (Tóth Benedek: Társadalomkritika és az egyetértés gépezete és Antal Attila: Noam Chomsky politikai gondolkodása), pedig Chomsky politikai aktivistaként kifejtett tevékenysége egyáltalán nem mellékes sem a saját életében, sem a hazája szellemi-politikai közéletében játszott szerepe szemszögéből (annak ellenére, hogy a leghatalmasabb amerikai médiamogulok továbbra sem tartanak igényt Chomsky jelenlétére és megszólalására).

A kötet szerkesztöje és összes szerzője büszke lehet arra, hogy az egész magyar tudóstársadalom nevében méltó módon köszönti a világ valaha élt egyik legnagyobb hatású gondolkodóját, a 90 éves Noam Chomskyt. És büszkék lehetnek még valami másra is. Nem ismerek még egy olyan köszöntö kötetet, amelyben az ünnepelt is köszönti az ünneplöit. De a szerkesztő jóvoltából, aki addig győzködte a szabódó Chomskyt, míg végül az ünnepelt ráállt, Chomsky személyes üzenetben maga is köszönti az öt ünneplőket (22-23.). Jellemző módon, az első rövid személyes mondat után azonnal a kedvenc tudományára tereli a szót, hogy azt higgyük, nem is őt, hanem a nyelvészetet ünnepeljük. Ebben részben igaza van. Az ő születésnapja alkalmából a tudományt is ünnepelik egyrészt azok, akik e kötet dolgozatait írták, másrészt mindenki, aki a kötetet olvassa.

(Kenesei István szerkesztő: Nyelv, biológia, szabadság: A 90 éves Chomsky jelentösége a tudományban és azon túl. Budapest: Gondolat Kiadó, 2019, 200 o.)

Czeglédi Csaba

kandidátus Eszterházy Károly Egyetem Anglisztika és Amerikanisztika Intézet 